\title{
Research on the Relationship between Capital Structure and Enterprise Value of the Sci-tech Enterprises
}

\author{
Juan Deng \\ Wuhan University of Technology, Wuhan, 430070, China \\ dj1321726296@163.com
}

Keywords: Capital structure; Enterprise value; GEM high-tech enterprises; Factor analysis

\begin{abstract}
Recently, the competitiveness and innovation of science and technology have become an important index to measure the comprehensive ability of the country. Firstly, based on the respective theoretical origin, this paper uses the description statistical analysis method to analysis the capital structure and enterprise value of science and technology enterprises from 2012 to 2014. Then, identify the assets and liabilities rate, long-term debt rate, the correlation between the current debt ratio and corporate value through the regression analysis. Finally, according to the results of empirical analysis, the enterprise external financing environment and optimization of enterprise internal governance structure is proposed to maximize the enterprise value.
\end{abstract}

\section{Introduction}

In our country become the largest emerging economies, the knowledge economy has become the mainstream, facing a large-scale industrial restructuring and upgrading of today, science and technology enterprises must be both a vanguard of economic transformation, vanguard, will be the main force, the main scientific and technological enterprises Status and value of unprecedented importance and significant. The classical economist William Petty argues that labor and land are resources, labor, and land as the father of wealth and the mother of wealth, respectively, in the source of wealth and value [1]. Adam Smith further developed the theory of labor value, in his "national financial nature and causes of the study," a book that "labor is a measure of the true value of all commodity exchange standards"[2]. David Ricardo has criticized both Adam Smith's theory of purchase value and income axiology, arguing that wage, profit, and rent are divisions of value [3]. J. Fred Weston argues that the theory of enterprise mainly discusses the rationality of enterprise existence, the organization form of enterprise, and the behavior of enterprise organization [4].

\section{Definition and Characteristics of GEM-based Enterprises}

Define the Science and Technology Enterprises. Science and technology enterprises can continue to introduce marketable high-tech products, competitive and sustainable development of the market enterprises [5]. Such enterprises are generally divided into two categories: one is usually the sense of science and technology enterprises, mainly engaged in information, electronics, bio-engineering, new materials, industrial technology products and new technology development and application of new energy and other field [6]. And the other is the development of supply chain management or franchise, knowledge-intensive companies characterized by customer information and preferences.

\section{GEM Characteristics of Science and Technology Enterprises}

Technology Innovation. Scientific and technological enterprises are the leading enterprise innovation, science and technology enterprise production and operation is the core of scientific and technological innovation, enterprise development is an important basis for technology development [7].

High Input. A scientific and technological achievement from the creative to the industrialization, the generally need to go through three stages of research and development, pilot and industrialization. 
High Yield. High-yield is associated with high-input, high-risk relative. Scientific and technological achievements of high technological content, brought together a large number of human wisdom, ordinary material through the human brain "processing", then worth double, the formation of technology-based enterprises relative to competitors in the technical advantages, and even bring a certain period of time Market monopoly, so that science and technology enterprises to obtain high returns ..

Analyze the Capital Structure of the Sci-tech Enterprises. Foreign research shows that, as companies continue to grow, mature, and its capital structure will change. In different stages of development of enterprises, their capital structure also has different characteristics [8]. In order to analyze the capital structure of science and technology enterprises from multiple perspectives, this paper selects 30 GEM enterprises, and finds the balance sheet of these 30 companies in 2012, 2013 and 2014 through the website of Securities Star with the indictors of Debt-to-assets ratio, Current Liabilities and Long-term debt ratio. The data of the capital structure indicators are sorted out through these financial statements. The result is shown in Table 1as follows:

Table1 Indicators of Capital Structure of Scientific and Technological Enterprises

\begin{tabular}{ccccc}
\hline Variable & Time & The minimum & The maximum & Average value \\
\hline $\begin{array}{c}\text { Debt-to-assets } \\
\text { ratio }\end{array}$ & 2012 & 0.0305 & 0.6686 & 0.2402 \\
& 2013 & 0.0305 & 0.5766 & 0.2676 \\
& 2012 & 0.034 & 0.5933 & 0.2892 \\
$\begin{array}{c}\text { Current } \\
\text { Liabilities Ratio }\end{array}$ & 2013 & 0.0305 & 0.6384 & 0.2158 \\
& 2014 & 0.033 & 0.5594 & 0.2423 \\
& 2012 & 0 & 0.2712 & 0.2497 \\
$\begin{array}{c}\text { Long-term debt } \\
\text { ratio }\end{array}$ & 2013 & 0 & 0.1077 & 0.0253 \\
& 2014 & 0 & 0.1834 & 0.0395 \\
\hline
\end{tabular}

We can see that the average asset-liability ratio of GEM enterprises in 2012, 2013 and 2014 is $0.2402,0.2676$ and 0.2676 respectively, and the average issuance ratio is $0.2158,0.2423,0.2497$, the trend of increasing year by year, the average long-term debt ratio of $0.0244,0.0253,0.0395$, also showed a year-on-year trend. You can find these data, although little change, but it is also growing year by year, just in line with the slow development of the GEM technology-based enterprises [9]. This also shows that the capital structure of the GEM technology companies in the debt financing ratio gradually increased, companies gradually give up the concept of equity financing, more attempts to debt financing [10].

Analyze the Enterprise Value of the Science and Technology Enterprise on the Current Situation. Based on the previous theory, this paper chooses the following four indicators to describe the value of science and technology enterprises. Through the Securities Star website to obtain the sample company's income statement, cash flow statement, balance sheet. And then use the data in these financial statements to calculate the enterprise value indicators, detailed data, and the result is shown in the Table 2. 
Table 2 Enterprise Value Indicators of Growth Enterprise

\begin{tabular}{ccccc}
\hline Variable & Time & The minimum & The maximum & Average value \\
\hline Roe & 2012 & -0.0893 & 0.8789 & 0.1655 \\
& 2013 & -0.1124 & 0.4934 & 0.1397 \\
& 2014 & -0.0313 & 0.5621 & 0.1145 \\
Total Asset & 2012 & 0.0025 & 0.23 & 0.0151 \\
$\begin{array}{c}\text { Turnover } \\
\text { Free cash flow }\end{array}$ & 2013 & 0.0017 & 0.26 & 0.0152 \\
& 2014 & 0.0018 & 0.24 & 0.0140 \\
& 2012 & $-129,258,993.73$ & $1,592,520,048.6$ & 87687492 \\
& 2014 & $-161,506,376.85$ & $2,557,945,711.3$ & 138857863 \\
& 2012 & -0.6312 & 21.095 & 0.9410 \\
& 2013 & -20.4563 & 1.2893 & -0.6177 \\
Net profit growth \\
rate
\end{tabular}

Profitability analysis: As can be seen from Table 2, the average return on net assets of the sample technology-based enterprises is $0.1655,0.1397$ and 0.1145 in the years of 2012 to 2014, which is decreasing year by year, indicating that the overall performance of the enterprises is Lower levels.

Analyze the Enterprise Value under Different Capital Structures. There are many factors that influence the value of the enterprise value of the scientific and technological enterprises of the GEM, this paper selects the asset-liability ratio to represent the capital structure and uses the clustering analysis to identify the different sections of the asset-liability ratio. The results are shown in Table 3.

As can be seen from Table 3, the sample technology-based enterprises in 2012, 2013 with the asset-liability ratio increases, return on equity, total asset turnover and return on net assets are increasing trend. At the same time, science and technology enterprises in 2012, 2013, 2014, asset-liability ratio of about $20 \%$ of the total sample of nearly $50 \%$, indicating that the overall sample of assets and liabilities is relatively low, enterprises should appropriately raise the assetIncreased risk tolerance, financial leverage is effective to play a role.

\section{Main Research Conclusions}

Through the regression analysis of 30 sample companies, this paper finds that the capital structure of science and technology enterprises is negatively correlated with the enterprise value, that is, with the decrease of capital debt ratio, the enterprise value will increase under certain conditions. Besides, the long-term debt-to-equity ratio has a negative correlation with the firm value. Corporate value decreases as long-term debt increases [11]. This is also the GEM of China's enterprises with the market environment. Therefore, reducing long-term debt can better improve corporate value. 
Table 3 Sample Firm Capital Structure Ratio The number of firms in each interval and the mean value of the firm

\begin{tabular}{|c|c|c|c|c|c|c|c|}
\hline $\begin{array}{c}\text { Debt-to-assets } \\
\text { ratio }\end{array}$ & $0-0.1$ & $0.1-0.2$ & $0.2-0.3$ & $0.3-0.4$ & $0.4-0.5$ & $0.5-0.6$ & $0.6-1.0$ \\
\hline 2012 (quantity) & 6 & 8 & 7 & 5 & 2 & 1 & 1 \\
\hline $\begin{array}{c}\text { Average return } \\
\text { on net assets }\end{array}$ & 0.0571 & 0.0884 & 0.2065 & 0.1442 & 0.2533 & 0.233 & 0.5327 \\
\hline $\begin{array}{c}\text { Average total } \\
\text { asset turnover }\end{array}$ & 0.0185 & 0.0166 & 0.0085 & 0.0069 & 0.0093 & 0.0068 & 0.0122 \\
\hline $\begin{array}{c}\text { Average net } \\
\text { profit growth rate }\end{array}$ & 1.3206 & 1.1152 & 0.2293 & 0.198 & 0.1482 & 0.1062 & 1 \\
\hline \begin{tabular}{c}
2013 (quantity) \\
\hline $\begin{array}{c}\text { Average return } \\
\text { on net assets }\end{array}$
\end{tabular} & 0.0406 & 0.1602 & 0.1165 & 0.1704 & 0.1505 & 0.2548 & 0 \\
\hline $\begin{array}{c}\text { Average total } \\
\text { asset turnover }\end{array}$ & 0.0199 & 0.0153 & 0.0065 & 0.0072 & 0.0062 & 0.0084 & 0 \\
\hline $\begin{array}{c}\text { Average net } \\
\text { profit growth rate }\end{array}$ & -1.194 & 0.939 & 0.118 & -0.8028 & -0.9585 & 0.1882 & 0 \\
\hline $\begin{array}{c}\text { 2014 (quantity) } \\
\text { on net assets } \\
\text { profit growth rate }\end{array}$ & 0.0731 & 0.1005 & 0.0794 & 0.1192 & 0.0821 & 0.1142 & 0 \\
\hline $\begin{array}{c}\text { Average total } \\
\text { Asset turnover }\end{array}$ & 0.017 & 0.006 & 0.0161 & 0.0062 & 0.0054 & 0.0057 & 0 \\
\hline $\begin{array}{c}\text { Average net } \\
\text { onge return }\end{array}$ & 5 & 0.3522 & 0.6484 & 0.1733 & 0.5361 & 0.2423 & 0 \\
\hline
\end{tabular}

\section{Acknowledgements}

The paper is supported by the National Social Science Foundation of China (Grant No.15ZDC022), MOE (Ministry of Education in China) Project of Humanities and Social Sciences (Project No. 15YJC790108, 16YJC630048),National Natural Science Foundation of China (Grant No. 71373199, 71602192), Science and technology fund of Hubei Province ( 2016ADC109) and"the Fundamental Research Funds for the Central Universities(WUT:2015VI013)".

\section{References}

[1] Jie Meng. Labor theory of value and the uncertainty in capitalist economy [J]. Frontiers of Economics in China, 2010, p. 54. 
[2] Santanu K. Ganguli. Capital structure - does ownership structure matter? Theory and Indian Evidence [J]. Studies in Economics and Finance, 2013, p.301.

[3] Scott J. Vitell, Encarnación Ramos Hidalgo. 'The Impact of Corporate Ethical Values and Enforcement of Ethical Codes on the Perceived Importance of Ethics in Business: A Comparison of U.S. and Spanish Managers' [J]. Journal of Business Ethics, 2006, p. 641.

[4] Hédia Fourati, Habib Affes. The Capital Structure of Business Start-Up: Is There a Pecking Order Theory or a Reversed Pecking Order? -Evidence from the Panel Study of Entrepreneurial Dynamics [J]. Technology and Investment, 2013, p.4.

[5] Ding Rongjing. Brief Introduction and Comment on the Western Capital Structure Theory [J]. Modern Economic Information. 2014, p13. (In Chinese)

[6] Zhang Wei. GEM profitability and the correlation between capital structure [J]. Modern Business Industry. 2015, p.2.(In Chinese)

[7] Ruan Sumei. Corporate governance and capital structure on the value of listed companies to create the impact of empirical research [D]. Hefei University of Technology 2014(In Chinese)

[8] Raju Majum dar, Indebtedness in the small and midcap segments: new evidences from Indian manufacturing sector. DECISION, 2014, Vol.41 (1), p.99.

[9] Alexander Moore, Stéphane Straub, Jean-Jacques Dethier. Regulation, renegotiation and capital structure: theory and evidence from Latin American transport concessions. Journal of Regulatory Economics, 2014, Vol.45 (2), p.209.

[10] Jian Liang, Liu Fang Li, Han-Suck Song. An explanation of capital structure of China's listed property firms. Property Management, 2014, Vol.32 (1), p.4.

[11] Feng $\mathrm{Wu}$, Zhengfei Guan, Robert Myers. Farm capital structure choice: theory and an empirical test. Agricultural Finance Review, 2014, Vol.74 (1), p.115. 